Original Paper

\title{
Deteksi Dan Pengelolaan Hipertensi Pada Remaja
}

\author{
Aini $^{1 *}$, Edi Kurniawan, Yan Reiza Permana1, Idham Halid ${ }^{1}$ \\ 1 Program Studi Teknologi Laboratorium Medik, Politeknik Medica Farma Husada Mataram, \\ Indonesia \\ 2 Program Studi Rekan Medik dan Informasi Kesehatan, Politeknik Medica Farma Husada Mataram, \\ Indonesia
}

DOI: $\underline{10.29303 / j p m p i . v 3 i 1.419}$

Sitasi: Aini., Kurniawan, E., Permana, Y.R., Halid, I. (2020). Deteksi Dan Pengelolaan Hipertensi Pada Remaja. Jurnal Pengabdian Magister Pendidikan IPA, 3(1). doi: https://doi.org/10.29303/jpmpi.v3i1.419

${ }^{*}$ Corresponding Author:

Aini, Program Studi

Teknologi Laboratorium

Medik, Politeknik Medica

Farma Husada Mataram,

Indonesia;

Email:

ainiemfh@gmail.com

\begin{abstract}
Abstrak: Tujuan pengabdian masyarakat ini adalah untuk memberikan pengetahuan kepada generasi muda secara umum dan kepada seluruh siswa tentang hipertensi yang meliputi deteksi dan penatalaksanaan dalam mencegah komplikasi dari hipertensi pada remaja. Manfaat diselenggarakanya kegiatan ini adalah untuk mendeteksi kejadian hipertensi pada remaja yang sering tidak disadari dan dapat berlanjut hingga dewasa sehingga membutuhkan penetahuan tentang penatalaksanaan dalam usaha untuk mencegah komplikasi. Target sasaran adalah remaja. Pelaksanaan kegiatan diawali dengan pertemuan dengan kepala MA. Nujumul Huda Desa lembar Kabupaten Lombok Barat untuk menetapkan waktu pelasanaan kegiatan yaitu pada 20 November 2019. Jumlah siswa yang menjadi sasaran kegiatan adalah 40 siswa kelas XII. Kegiatan yang dilakukan ini menjadi topik menarik terkait dengan deteksi Hipertensi pada remaja dikaitkan dengan minat siswa kelas XII yang akan lulus sekolah dan mengikuti berbagai seleksi untuk sekolah kedinasan atau seleksi calon anggota POLRI.
\end{abstract}

Kata Kunci: Deteksi, Hipertensi; Remaja, pengelolaan.

\section{Pendahuluan}

Hipertensi merupakan the silent killer sehingga pengobatannya seringkali terlambat. Berdasarkan laporan $\mathrm{WHO}$, dari 50\% penderita hipertensi yang diketahui, $25 \%$ di antaranya mendapat pengobatan, tetapi hanya $12,5 \%$ di antaranya diobati dengan baik (Tjekyan, 2014). Penderita hipertensi di indonesia iperkirakan 15 juta orang, tetapi hanya $4 \%$ di antaranya merupakan hipertensi terkontrol(Angesti, Triyanti, \& Sartika, 2018).

Hipertensi merupakan satu masalah kesehatan. selain pada pada orang dewasa hipertensi juga dapat terjadi pada remaja. Hipertensi pada remaja menjadi masalah karena dapat berlanjut pada usia dewasa. Hipertensi memiliki risiko morbiditas dan mortalitas yang lebih tinggi. prevalensi secara klinis sangat sedikit pada anak dan remaja dibanding pada dewasa, namun cukup banyakbukti yang menyatakan bahwa hipertensi esensial padaorang dewasa dapat berawal pada masa kanak-kanak dan remaja(Kamadjeu et al., 2006).

Banyak bukti yang mendukung konsep hipertensi esensial berawal dari masa kanakkanak meskipun hipertensi esensial lebih sering terjadi pada remaja dibanding pada anak. Remaja dengan hipertensi esensial kebanyakan tanpa gejala (asimtomatik) dan 
sering terdeteksi hanya pada saat pemeriksaan rutin Obesitas sering dihubungkan dengan hipertensi esensial dan dijumpai pada hampir $50 \%$ kasus. Riwayat keluarga yang menderita hipertensi sering dijumpai.(Angesti, Triyanti, \& Sartika, 2018)

Hasil penelitian ang dilakukan oleh (Shaumi \& Achmad, 2019) menunjukkan kualitas tidur, indeks massa tubuh menurut umur (IMT/U), dan riwayat hipertensi keluarga memiliki hubungan yang bermakna terhadap kejadian hipertensi. Kualitas tidur yang buruk memiliki risiko 4,1 kali lebih besar, IMT/U yang tinggi memiliki risiko 4,85 kali lebih besar, dan riwayat hipertensi keluarga memiliki risiko 3,9 kali lebih besar untuk mengalami hipertensi. Kesimpulan dari penelitian ini adalah kualitas tidur yang rendah, status gizi berlebih (IMT tinggi), dan adanya riwayat hipertensi keluarga dapat meningkatkan risiko remaja mengalami hipertens.

\section{Metode Pelaksanaan}

Sebelum melakukan sosialisasi tim pengabdi mengirimkan surat terlebih dahulu mengenai permohonan untuk melakukan sosialisasi dengan tanggal dan waktu yang sudah dicantumkan dalam surat. Selanjutnya pihak sekolah memberikan jawaban mengenai kesepakan waktu dan jam untuk pelaksanaan sosialisasi tersebut.

Metode yang digunakan pada sosialisasi ini adalah penyuluhan dan melelui presentasi dengan power point sesuai dengan tema. Setelah selesai materi siswa diberi kesempatan untuk bertanya. Pada Saat yang bersamaan juga dilakukan pemeriksaan hipertensi terhadap siswa. Siswa kelas tiga menjadi bisa untuk mengetahui berapa tensi karena banyak dari sisiwa kelas tiga sedang mmpersiapkan diri untuk mengikuti seleksi kepolisian dan test ikatan dinas lainya. Jadi bersamaan dengan selesainya sosialisasi dilajutkan dengan pemeriksaan kesehatan

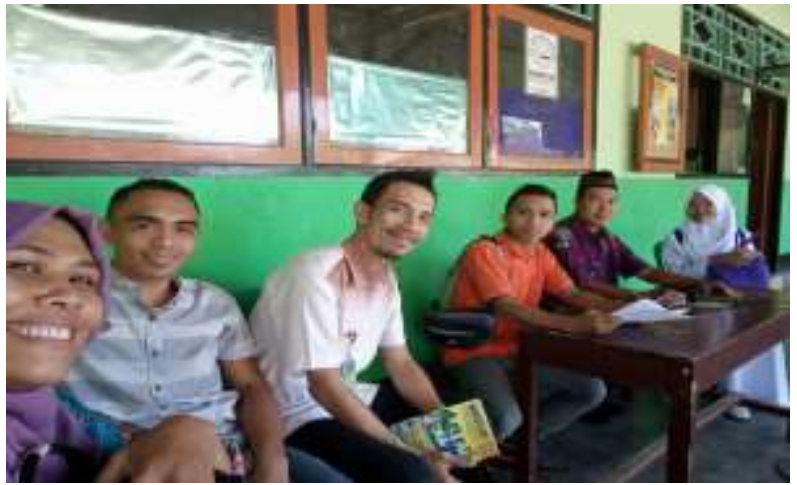

Gambar 1 Koordinasi waktu pelaksanaan Pengabdian

\section{Hasil dan Pembahasan}

Kegiatan pengabdian kepada masyarakat telah dilaksanakan di MA. Nujumul Huda Desa lembar Kabupaten Lombok Barat dan waktu pelasanaan kegiatan yaitu pada 20 November 2019. Saat penyajian materi diberikan beberapa sisiwa mengajukan pertanyaan kaitanya dengan hipertensi dan penyebabnya. Penjelasan di berikan secara lugas menyenai penyebab hipertensi yang merupakan penyakit yang umum di masyarakat.

Penyuluhan ini menjadi menarik karena selama ini paradigma yang diketaui siswa adalah bahwa hipertensi hanya terjadi pada orang tua dan dengan adanya penyuluhan ini para siswa memahami pentingnya untuk mendeteksi adanya hipertensi pada remaja Penyebab hipertensi dan Pengelolaan hipertensi pada remaja.

Hipertensi pada hipertensi remaja dibagi menjadi beberapa bagian yaitu ringan jika 140/90 - 149/99 mm Hg, sedang 150/100 - 159/109 $\mathrm{mmHg}$ berat $=160 / 110 \mathrm{mmHg}$. Penyebab hipertensi pada remaja Penyebab hipertensi pada remaja (usia 13-18 tahun) yang paling sering adalah hipertensi esensial $(80 \%)$, diikuti penyakit ginjal. Hipertensi esensial pada remaja dapat merupakan lanjutan dari masa kanak-kanak dan berlanjut ke masa dewasa (Saing, 2016). Hipertensi pada remaja sering terjadi karena obesitas. 


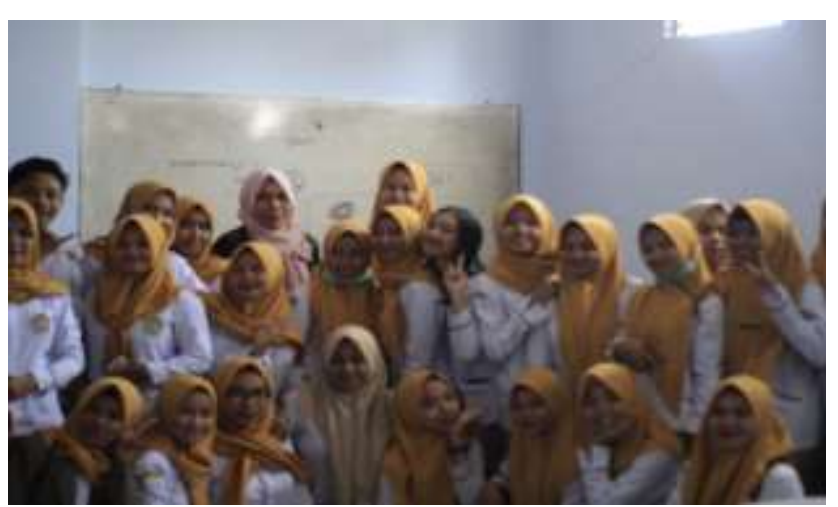

Gambar 2. Dokumentasi Setelah Kegiatan Berakhir

\section{Kesimpulan}

Kegiatan ini menyimpulkan bahwa: 1) Pengabdian telah dilakukan dengan terget jumlah siswa sasaran sebanyak 40 sisiwa kelas XII; 2) Hasil evaluasi dapat dilihat pada jumlah sisiwa yang mengajukan pertanyaan setelah penyampaian mater; 3) Jika program ini dapat dilakukan pad a setiap sekolah akan dapat mmberikan dampak yang baik terhadap deteksi hipertensi pada remaja.

\section{Ucapan Terimakasih}

Terimkasih Kepada LPPM politeknik medica Farma Husada yang telah membrikan dukungan hingga terlaksananya sosialisasi ini.

\section{Daftar Pustaka}

Angesti, A. N., Triyanti, T., \& Sartika, R. A. D. (2018). Riwayat Hipertensi Keluarga Sebagai Faktor Dominan Hipertensi pada Remaja Kelas XI SMA Sejahtera 1 Depok Tahun 2017. Buletin Penelitian Kesehatan, 46(1), $1-10$. https://doi.org/10.22435/bpk.v46i1.41

Kamadjeu, R. M., Edwards, R., Atanga, J. S., Unwin, N., Kiawi, E. C., \& Mbanya, J. C. (2006). Prevalence, awareness and management of hypertension in Cameroon: Findings of the 2003
Cameroon Burden of Diabetes Baseline Survey. Journal of Human Hypertension, 20(1), 91-92. https://doi.org/10.1038/sj.jhh.1001936

Saing, J.H. (2016). Hipertensi pada Remaja. Sari Pediatri, 6(4), 159. https://doi.org/10.14238/sp6.4.2005.159$\underline{65}$

Shaumi, N.R.F., \& Achmad, E.K. (2019). Kajian Literatur: Faktor Risiko Hipertensi pada Remaja di Indonesia. Media Penelitian Dan Pengembangan Kesehatan, 29(2), 115-122. https:// doi.org/10.22435/mpk.v29i2.110 $\underline{6}$

Tjekyan, R.M.S. (2014). Angka Kejadian Dan Faktor Risiko Hipertensi Di Kota Palembang Tahun 2013. 401(1), 1-11. Retrieved from http://download.portalgaruda.org/articl e.php?article $=471735 \& v a l=9692 \&$ title $=A n$ gka 